\title{
Article
}

\section{From local survivalism to foreign entre- preneurship: the transformation of the spaza sector in Delft, Cape Town ${ }^{1}$}

\author{
Andrew Charman, Leif Petersen and Laurence Piper \\ andrew.charman@livelihoods.org.za,leif.petersen@livelihoods.org.za, \\ lpiper@uwc.ac.za
}

\begin{abstract}
Small, home-based grocery stores, known as spaza shops, are ubiquitous throughout the township areas of urban South Africa, constituting an important business in the informal economy. In recent years, this retail market has become a site of fierce competition between South African shopkeepers and foreign entrepreneurs, especially Somalis, and is often cited in the media as one reason behind the xenophobic attacks on foreigners. Drawing on original data collected in the Delft township in the city of Cape Town, this paper demonstrates that foreign entrepreneurs, overwhelmingly Somalis, have come to own around half of the sizeable spaza market in Delft in the last five years. This increase is attributable to larger scale and price competitive behaviour as these entrepreneurs operate collectively in terms of buying shops, and stock, as well as in stock distribution. Also important are some more customer friendly services too. Compared to the more 'survivalist' local business model where individual owners look to supplement existing household income rather than generate an entire livelihood, the Somali business model has rapidly outcompeted local owners, bringing spaza prices down and forcing many locals to rent out their shop space to foreign shopkeepers. Consequently, while South African shopkeepers resent the Somali influx, most consumers appreciate the better prices and improved service. The rise of Somali shopkeepers thus represents a transformation of business practice in the spaza sector from survivalist to entrepreneurial modes.
\end{abstract}




\section{Introduction}

Spaza shops are often cited as examples of micro-entrepreneurial endeavour and success within the informal economy of South African townships. The term 'spaza' is taken from the isiZulu language, meaning 'hidden' (Bear et al 2005), and emerged in the apartheid era when business opportunities for black entrepreneurs were restricted. These micro-convenience stores traded in a clandestine manner to provide township residents with local access to everyday goods otherwise only available at distant supermarkets. Over time the scale of the spaza shop market has grown steadily (Marketing Mix 1995), in part due to the greater levels of disposable income in the hands of historically poor communities (Van der Berg and Louw 2003:7). While there is no precise data on the current size of South Africa's spaza market, a detailed investigation in 2002 estimated that spaza shops account for $2.7 \%$ of total retail trade, equivalent to approximately R8 billion in value (Ligthelm 2005:202). More recently, SPAZA News (2011) estimates that there are more than 100,000 spaza enterprises with a collective turnover of R7 billion.

Since about 2005, a growing class of entrepreneur retailer has emerged as a major economic player within spaza markets. These entrepreneurs, characterised by 'opportunity-motivated' individuals (as described in Ligthelm 2005:204; see also Charman and Petersen 2010), have steadily outcompeted many survivalist businesses (estimated to be $75 \%$ of all enterprises by Ligthelm 2005:204). The majority of these retailers are immigrants, and the ensuing consequences of their rising dominance has a distinct national or ethnic character, pitting South African shopkeepers against immigrants from countries including Somalia, Egypt, Ethiopia, Rwanda, Tanzania, Pakistan and Bangladesh. This is cited as a source of tension between South Africans and foreigners, especially Somalis. Thus in the xenophobic attacks of 2008, a considerable number of foreign operated spaza shops were looted and burned down. Aside from this event, foreigner storekeepers, in particularly the Somali community, continue to report attacks on their possessions and persons (Charman and Piper 2011). The advent of foreign storekeepers is thus widely associated with social conflict as well as a changing business environment, and therefore any research of this sector ought to cast light on these issues too.

This paper provides a street level insight into the competition between local and foreigner retailers in one case study. The study is set in Delft South and a portion of Eindhoven (hereafter Delft), a relatively poor township on the outskirts of the City of Cape Town (see Figure 1). The objective of the 
research was to investigate the extent to which immigrant entrepreneurs have entered the spaza market and the strategies they have utilised to capture market share, as well as popular attitudes towards these dynamics. To this end the paper begins by situating the topic within the literature on the informal economy. We then outline the methodology, before specifying the key findings and the emergent analysis.

In brief we discover a story of the relatively rapid capture of the spaza retail market by larger-scale, collective businesses run by Somalis. Further, these immigrants employ entrepreneurial business practices, especially price competition, to outcompete and in many cases, take over, South African shops typically run on more individual and 'survivalist' lines. Importantly, the latter includes the local practice of competing on location rather than price, reducing profit margins but also retaining market entry opportunities for nearly anyone looking to supplement income. The advent of a price-competitive business model has upped rates of profit and reduced prices but simultaneously reduced market access options. In terms of popular attitudes towards this change, our research revealed that while South African shopkeepers resent the Somali advent, most consumers appreciate the better prices and improved services.

\section{The informal economy and spaza shops}

The informal economy refers to the existence and activities of informal businesses (and their employees) outside the legal and institutional regulatory framework. The concept refers to enterprises and workers that are unregistered and unincorporated (Statistics South Africa 2010). In its broadest interpretation the informal economy encompasses illegal activities such as crime and tax avoidance and activities that, apart from the non-compliance with specific national and local laws, are otherwise legal such as street trading (see Ligthelm 2008). It includes all activities for which income is unreported for taxation. In this article we refer specifically to that component of the informal economy situated spatially within poor communities, where small-scale, unregistered and usually family-based firms with less than five employees predominate. These enterprises fall within the definition of micro-enterprises, as set out in the Small Business Act (1996 and 2004); that is, an enterprise with less than five full time employees, a turnover below R0.2million and total gross assets valued at less than R0.1 million. Scholars argue that informality should be conceptualised in terms of gradients of formalisation, rather than absolutes (Maloney 2004:1168). This is particularly 
evident in the spaza market as these micro-enterprises sometimes abide with particular regulatory requirements (such as registering as businesses) and ignore others such as zoning requirements.

The current state of knowledge of the informal economy still requires much development, given that existing theoretical frameworks do not adequately explain the internal dynamics of micro-enterprises in the informal economy. It is not necessarily correct to see the informal economy as sphere of marginalisation, although Meagher (2005: 268) argues that, in Africa, the informal sector is mostly populated by the poor and marginalised, and that genuine entrepreneurs are a small minority. Studies have found that there is a rationale, on the basis of an implicit cost-benefit analysis, for microentrepreneurs and informal workers to position themselves in the informal economy (see Becker 2004, Charman and Petersen 2010, Devey et al 2006, Petersen and Charman 2008). Thus no generalisation can be made on whether the terms of employment in informal businesses are inferior to the formal labour market or whether the failure of micro-enterprises to expand indicates that they are trapped in a low growth cycle. Through the increasing availability of qualitative studies, the field of knowledge now recognises the rules of doing business in the informal economy do not (necessarily) mirror those of formal businesses. For example, working capital is typically raised from family and friends, where surety rests on the strength of social relations and repayment terms are flexible. Doing business through social networks and family makes sense, as Maloney (2004:1168) points out, because it enables the 'micro entrepreneur to enforce implicit contracts, insure against risks', whereas 'participating in the formal institutions of civil society is needlessly expensive'.

The informal economy in developing countries such as South Africa provides an entry point for persons otherwise excluded from the formal labour market due to a lack of education and skills to pursue business opportunities or gain employment. There is a great diversity of economic activities and forms of employment in informal micro-enterprises (see Valodia et al 2007). The majority of these entrants, however, either engage in trade, often starting off through selling goods on the street or by working for others doing the same, or provide personal services such as hair care or child minding. It is thought that about $50 \%$ of the economic activity of the poor in the South African informal economy involves trade (Ligthelm 2008:373). The considerable demand for goods and services within poor communities, especially where formal businesses are largely absent, provides an 
opportunity for the emergence of micro-enterprises that are modelled on formal businesses, but operate informally. It is in this context that spaza shops conduct their business.

The great majority of spaza shops operate informally without a license to trade (Chebelyon-Dalizu et al 2010). A number of studies have investigated the enterprise characteristics of spaza shops (Cant and van Scheers 2007, Chebelyon-Dalizu et al 2010, Ligthelm 2005, Perry 1989). Their success was based on three factors: first, the role of the extended family in providing startup capital and labour; second, the business location, physically operating from rooms of residential households and spatially situated close to people's homes; and, third, the informal rules that permitted each spaza a small share of the market on roughly equal terms. The research also emphasises the importance of the social ties between the micro-entrepreneur and his/her neighbours and the broader community, which determines the terms on which lines of credit are extended (Ligthelm 2005:205). At the same time credit is also recognised as a potential cause of business failure.

Whilst the spaza market offers potential opportunity for success, many new entrants fail. Although no accurate data on the survival of spaza business is available, it is thought that up to $50 \%$ of new entrants are unable to sustain their businesses for longer than five years, though those that do survive have great longevity. The Ligthelm (2005:205) study reports that an impressive $40 \%$ of spazas in the urban context had been in operation for longer than five years. It is significant that existing spaza shop microentrepreneurs were willing, until the arrival of immigrant shopkeepers, to permit a continuous stream of new entrants into the market. Before this time, spaza shops rose and fell, but accounts of foreigner competition and/or violent entrepreneurship from competitors were rare.

There is anecdotal evidence, confirmed during our research, that the historically low barriers to entry in the spaza market was attributable to some form of collusion in price setting, a practice widely evident among street traders (Charman and Petersen 2007). In this regard, Charman and Petersen have shown that the use of price competition is considered unfair and unethical. Instead street traders compete through non-price mechanisms, including their spatial location, product presentation, customer engagement, the bonds of clan and kinship, and by seeking supernatural support (Charman and Petersen 2007, Petersen and Charman 2008). Price competition is strongly discouraged among these informal micro-entrepreneurs because 'fixed' prices help to ensure that market entry barriers remain low, thus keeping the 
market open for others who equally need a means of survival. This informal 'rule' of doing business enables street traders to sustain their microenterprises for many years, for under fixed prices, they have an equal opportunity to sell their goods or services even though growth prospects are limited for all.

This outlook underpins the 'survivalist' practice identified in much of the research on the South African informal economy. Ligthelm (2008) proposes, for example, that less than $15 \%$ of all micro-entrepreneurs have the necessary skills and business acumen to expand and develop their business. Unlike classical opportunity-driven entrepreneurship, the strategy of the survivalist micro-entrepreneur is to derive an income as a means of employment, often until such time as a better paying job becomes available, though not necessarily to expand the business if growth requires the elimination of competition.

These insights help inform the key finding of this study, namely that the conflict between local and foreigner spaza retailers is less about identity politics than it is about fundamentally differing approaches towards business. Most local spaza micro-enterprises, we propose, had not historically engaged in price competition but rather operated on the basis of their location and relationships with clients. Foreigner entrepreneurs, in contrast, are known to use price competition and bulk procurement strategies to aggressively compete with local spaza shops through undercutting their price (Knowledge Link Services 2009: 39-40), a practice confirmed by this study.

\section{Methodology}

The study looked to explore the scale, nature, and perception of the spaza sector in one study site. It is fundamentally a case study driven approach, although extensive use of both quantitative and qualitative methods is made. In terms of sites, the research was confined to the residential area and high street of Delft that fringes the City of Cape Town. The case study site was chosen because of the known penetration of foreigner shopkeepers into the market and, as a consequence, of the history of tensions between immigrants and South African residents in the area (see Charman and Piper 2011). The case study site comprises a racially diverse community, made up of 'coloured' and 'black African' (predominantly Xhosa) people, whose heterogeneity is reinforced through the diversity of religions (Christian, Islam, traditional) and cultural belief systems. 
Figure 1: Spatial Distribution of Micro-Enterprises, Delft South / Eindhoven

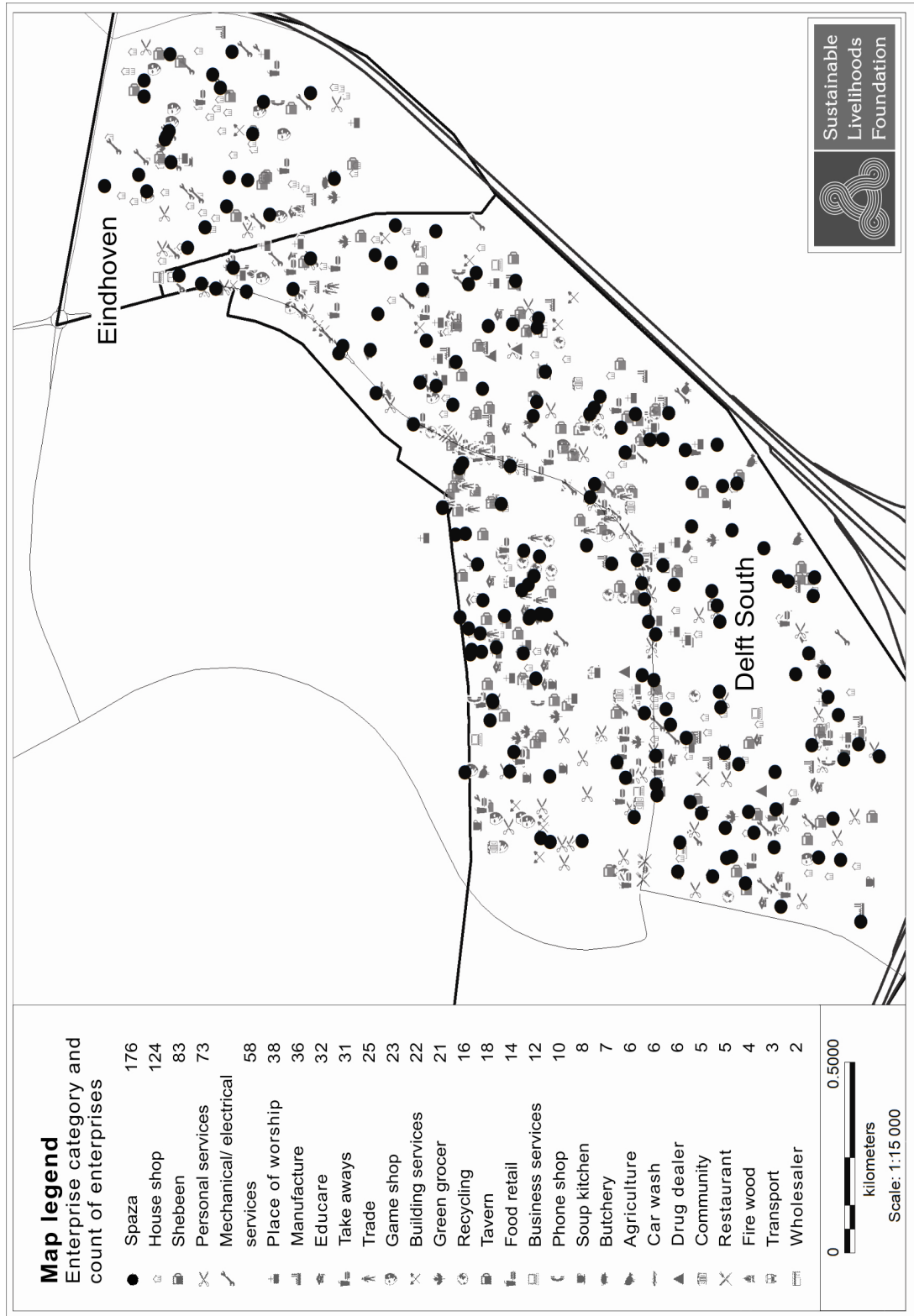


The township of Delft was established as a new housing development in the mid-1990s and has since expanded to a settlement of about 12,000 households and population of roughly 50,000 persons (Seekings et al 2010). Within the population of working age, $61 \%$ are either unemployed or underemployed, with most of the $39 \%$ who are employed working in semi-skilled jobs within the service and manufacturing sectors (CensusPlus 2007). Unemployment is noticeably higher in Delft South (38\%), in comparison to the portion of Eindhoven (27\%) included within the study site. CensusPlus (2007) estimates the monthly income per capita for Delft South at R732 (\$108) and Eindhoven at R1008 (\$149) per month. Poverty in both communities is deep and widespread.

In exploring the scale of the spaza shop economy the research looked to map every shop spatially. This process entailed a street survey and the recording of all publicly recognizable micro-enterprises and communal resources such as religious places. A five person racially and linguistically representative team of researchers (including a Somali national) traversed the area on bicycle, progressively covering the area of Delft street by street. Whenever the research team encountered a micro-enterprise, they recorded its location and description of its activities using a geographical positioning system (GPS) device. Upon the completion of the street mapping process, the waypoint data was then analysed and the businesses classified according to enterprise typologies. The resulting database was used to develop a series of geo-spatial maps, showing the location of each business, and the distribution of enterprises by category.

To explore the nature of business practices interviews were conducted with each shopkeeper that included questions on the prices of various products. The questionnaire was applied to only those micro-enterprises that had signage, branding with an identifiable name, and which contained a diversity of grocery items including at least four of the items on the survey list. The reason for this was to distinguish spazas from smaller 'house shops' as spazas are dedicated full time businesses that occupy the working hours of the micro-entrepreneur, rather than 'house shops' operating on a more adhoc basis, usually week-ends. The research looked to record the retail price of six everyday necessities: one litre full cream milk, six eggs, bread (either a half/full loaf of 'Blue Ribbon' branded white bread), sugar $(250 \mathrm{~g} / 500 \mathrm{~g} / 1 \mathrm{~kg})$, Coca Cola (340ml/450ml $/ 1500 \mathrm{ml}$ ), Jive soft drink (two litre), Double 'O' soft drink (two litre), single cigarettes (premium and economy brands, ie contraband). These commodities (along with paraffin) are considered the 
main items sold through spazas (SPAZA News 2010; see also Knowledge Link Services 2009:32, and Ligthelm 2005, 2008). The questionnaire took into consideration the different quantities and brands under which these items are sold, thus ensuring comparability between stores. It also recorded the nationality of the storekeeper and enquired whether the business was selfrun or employee-run. The data was compiled into a database whereupon an analysis of price distribution was undertaken.

Lastly, to explore attitudes, a household survey was undertaken, and a number of interviews and focus groups were conducted with key informants including the Somali Association of South Africa, South African shopkeepers, the police, and fellow researchers. As the findings of the mapping process showed a comparatively even distribution of foreign operated spazas (see Figure 2) the researchers decided to select the household transect on an arbitrary (non-random) basis. The identified transect was located within the poorest quadrant of study site, comprising both coloured and black households. The researchers specifically sought to avoid selecting an area of demographic homogeneity so as to be able to compare the questionnaire responses according to race. The survey posed questions to the informants on whether or not they had run a spaza, the particular spaza shop/s they purchased items from most often, the frequency of purchases, their views on business opportunities for setting up a spaza within the neighbourhood, and on the role of spaza micro-entrepreneurs within the community. A total of 50 households were surveyed comprising $72 \%$ black informants and $28 \%$ coloured informants. Some 34 of the informants $(68 \%)$ were women. The majority of all informants were adults of working age (84\%). Notably, the sample of 50 is too small to generalise from, and resources prevented a greater sampling, but taken together with the other interviews, focus groups and documented evidence, the survey helps to confirm the broad strokes of what we found in other data sources.

In terms of interviews, semi-structured interview schedules were conducted with the leaders of the Somali Association of South Africa, the police, the local councillor and other community leaders. In addition, during the course of the field research, the researchers engaged, informally through open-ended discussions, with dozens of spaza shop micro-entrepreneurs, both South Africans and immigrants. These interactions enabled the researchers to explore questions on the business dynamics, such as supply chains, trends in turnover, fixed costs and, for those struggling with increased competitiveness, their coping strategies. Further, in order to 
Figure 2: Spatial Distribution of Spaza Shops, Delft South / Eindhoven

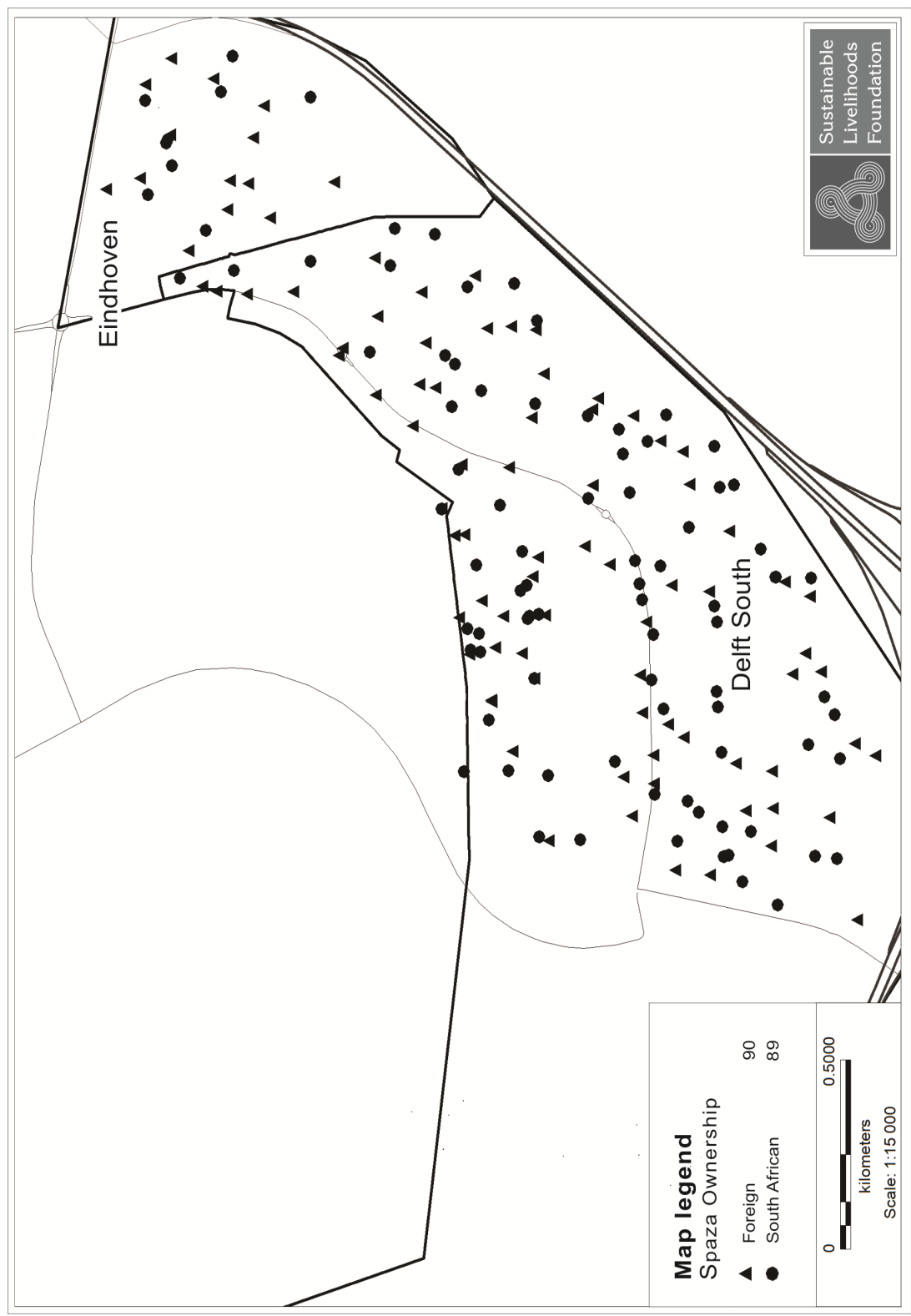


gauge local shopkeeper views on the historic practices and recent changes in the Delft spaza market, the researchers facilitated a focus group discussion with eight South African spaza shop owners.

\section{Findings}

The findings emerge in the order identified in the research methodology section starting with the number, ownership, and spatial distribution of spazas; price competitiveness and other businesses; and South African responses, including popular attitudes. The key findings include, first, the remarkable scale of the informal economy in Delft, and especially the comparative size of the spaza market; second, the substantial portion of foreign ownership, and its recent arrival into the market; third, the importance of price competitiveness to this success, but also other business practices and, fourth, the inability of South African spaza shops to match the competitive challenge with customers choosing foreigner-run shops.

\section{The scale of the informal economy of Delft}

The scale of the informal economy in Delft is much larger than officially thought. The City of Cape Town, for example, identified 123 businesses within Delft South in a recent strategic planning survey. Our research identified 818 registered and unregistered micro-enterprises, whose spatial distribution is presented in Figure 1. The various categories of microenterprises identified are shown in Figure 3.

Figure 3: Identified Micro-Enterprises, Delft 2011

\begin{tabular}{|l|l|l|l|l|l|}
\hline Enterprise Category & No & Enterprise Category & No & Enterprise Category & No \\
\hline Agriculture & 6 & Game Shops & 32 & Seven Eleven & 2 \\
\hline Building Services & 22 & Green Grocer & 21 & Shebeen & 83 \\
\hline Business Services & 12 & House Shop & 124 & Soup Kitchen & 8 \\
\hline Butchery & 7 & Manufacture & 36 & Spaza & 179 \\
\hline Car Wash & 6 & $\begin{array}{l}\text { Mechanical / } \\
\text { Electrical Services }\end{array}$ & 58 & Take-Aways & 31 \\
\hline Drug Dealers & 6 & Personal Services & 73 & Tavern & 18 \\
\hline Educare/ Crèche & 32 & Phone Shop & 10 & Trade (general) & 25 \\
\hline Fire wood & 4 & Recycling & 16 & Transport & 2 \\
\hline Food Retail & 14 & Restaurant & 5 & Wholesaler & 3 \\
\hline
\end{tabular}


Some of these micro-enterprises operate part-time, such as the house shops, providing no additional employment and are run to supplement other household income. At least three quarters conduct business on a full-time basis and provide employment to persons other than the business owner, commonly as some kind of casual work. The role of informal businesses in providing employment and generating local economic activity through a multiplier process is evident from the diversity, frequency and spatial distribution of the identified enterprises, and requires further exploration to better understand the real character of South Africa's economy including the labour market.

\section{Spaza market ownership}

In our survey we identified 179 spaza shops in Delft. If we missed any, this number will only be higher. The spatial distribution of these stores is remarkably even (see Figure 2); unlike some micro-enterprises (particularly specialist personal services and building services) that are concentrated along transport routes. This implies that the market is both common and localised to those on foot. Of the 179 spaza shops, 90 (or 50\%) are foreign operated and of these 80 are Somali-run. The spatial distribution between local and foreign run shops reflects the evenness in the general distribution - that is foreigners do not dominate any particular space but are spread across the area evenly, reinforcing our claim that the ownership of shops is market-driven rather than identity-based.

Thus in virtually all neighbourhoods a foreigner run spaza currently operates in direct competition to local spazas. The nationalities of the foreigner shopkeepers include Bangladeshis (the second largest group), Egyptians, Ethiopians, Rwandans and Tanzanians, though none of these nationalities have the numbers or enterprise muscle of the Somali entrepreneurs. It is the view of most South African spaza shopkeepers with whom we engaged in the course of the research that the spaza market in Delft has become 'over-saturated' with the situation worsening as new immigrant groups (especially Bangladeshis and Ethiopians) seek to gain a slice of the market.

Notably, the majority of foreigner owned spazas rent the premises from which they conduct their business from local residents. In recent times an increasing number of foreign run spazas operate out of shipping containers or prefabricated timber ('Wendy') houses, located either in residential properties or on public land. The rental agreements are made with the 
homeowners who, in most cases, still reside on site, but lease part of their house or land. In many instances, the landlords are persons who once operated a spaza on their property but find it more lucrative to rent their business or shop space to the foreigner, given their inability to compete in the changing market environment. Upon assuming ownership, some new owners re-brand their shops, referring to them as tuck shops or cash stores rather than spazas, though the name spaza persists in most established businesses.

The rental varies between about R500 (\$74) and R2,500 (\$373) per month (excluding water and electricity) (typically R1,000/\$149 for a poorly developed business), depending on the range of facilities that are provided. Some entrepreneurs pay rents as high as R3,500 (\$522), though in these instances the researchers learnt that some form of protection services is included in the rental. Where rentals are low, the shopkeepers have invariably built a new structure from which to conduct business, which the homeowners will then acquire at the conclusion of the rental agreement. These lease agreements are usually entered into for three years, though it is evident that the terms of the contract are not enforced and instead are superseded by verbal agreements. In most foreign run stores there has been a rapid turnover in ownership, as well as in their employees, with the store itself seen as a business investment which is usually sold for between R25,000-R35,000 $(\$ 3,730-\$ 5,223)$ to another foreign investor, or more usually a group of investors, after a year or two.

The spatial distribution of spaza shops directs attention to the intimate link between market share and physical location. In order to understand this relationship, the research surveyed 50 households, located within a tract comprising Nannabessie and Mango Streets (the survey transect is shown in Figure 4). Of the 50 informants, 38 (76\%) reported shopping at what they consider to be the nearest spaza on a daily or regular basis, regardless of its ownership status so long as the prices are deemed competitive. The remainder either preferred specific shops that provided a better service, were cheaper, or offered certain products (such as electricity). A few informants refused to support particular spazas even if these were the closest to their homes, citing previous disagreements they had had with the shopkeeper or because they considered the shopkeepers rude, ill mannered, or unhygienic. 
Figure 4: Transect, Household Survey

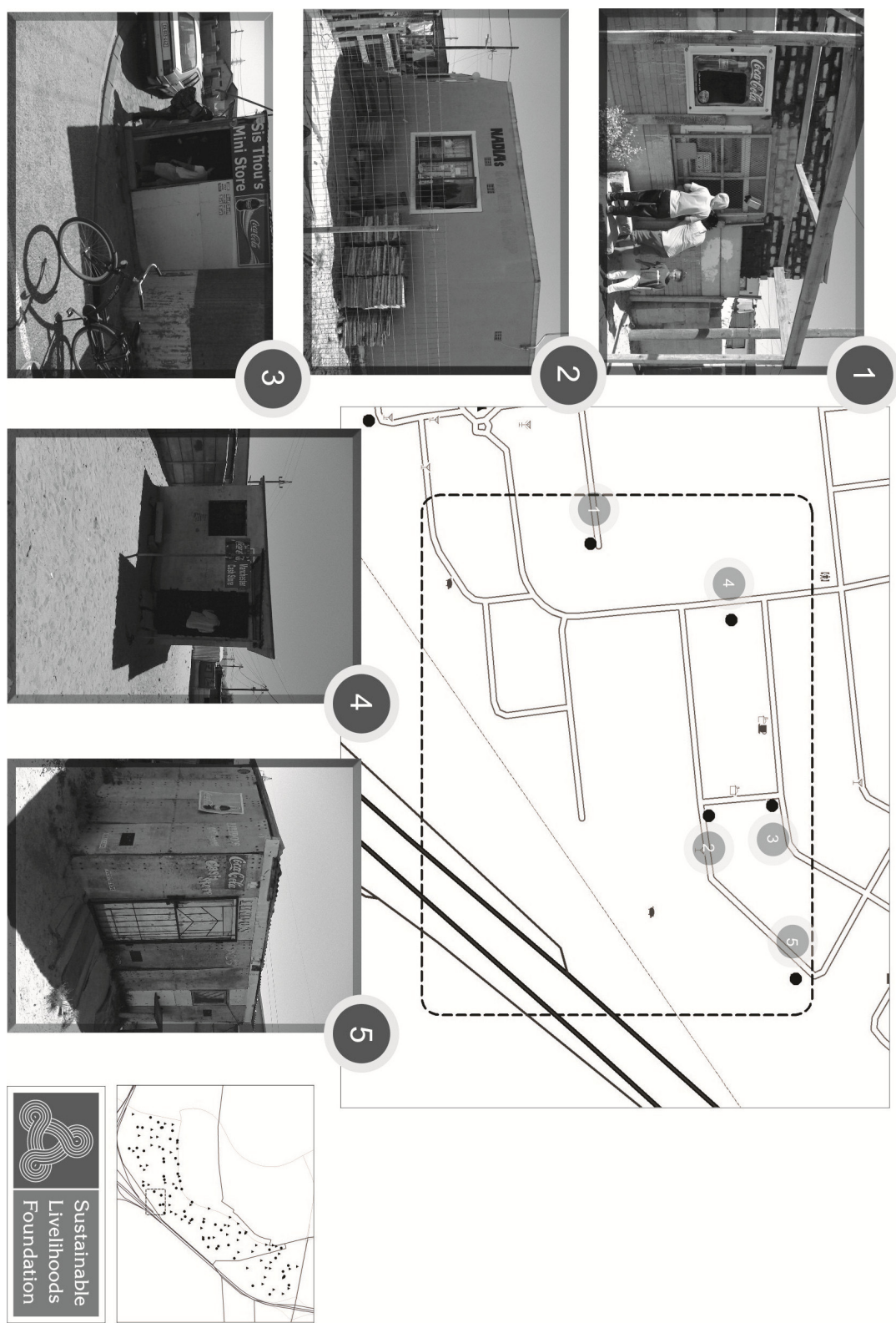


Store location is evidently a pre-condition for success. This finding is evident to foreigner shopkeepers whose businesses are evenly spread across the research site, regardless of how their positioning may impact on South African spazas (see Figure 2). The spazas frequented by our informants included both shops run by South Africans and immigrant run stores. Whilst most of the informants said that they purchase basic necessities on a daily basis from their local spaza, the majority ( 31 of 52 responses) conduct a 'big shop' (implying a supermarket visit) only once per month. Ten reported conducting a 'big shop' on a weekly basis. On these occasions, the informants elect to travel to the nearest supermarkets that are located outside of Delft, some in the distant business centres. This finding confirms that the residents of the survey transect are considerably reliant on spazas, not simply for milk, bread, and soft drinks, but also for staple food supplies and supplementary groceries.

\section{The significance of price}

The research compared the prices of six items from 106 spaza shops. Of these shops, 56 were owned or run by South Africans, 45 by Somalis and five by Bangladeshis. The average price for these items within the three groupings was examined. The results of the price survey are presented in Figures 6 and 7. The survey found that on all price items except for Coca Cola $(340 \mathrm{ml}$ and $1500 \mathrm{ml}$ ) the average price of Somali-run shops was lower than those in South African or Bangladeshi shops (the three nationalities providing cohorts for comparative purposes). Although the comparative average price difference is relatively small, as illustrated in the bar graph, it is sufficiently large to provide price sensitive consumers with notable savings. It also largely conceals the history of downward price pressure that emerged during the qualitative research. In the words of one South Africa spaza owner:

Somalis sell 'daily things' like bread and milk at cost price, which forces me to do the same in order to keep my customers. But ... in Mitchells Plain [a neighbouring suburb] the people at least make R2 profit per loaf.

The aggregate price difference of the six items, contrasting the South Africans, Somali and Bangladeshi shops, is shown in Figure 5. The South African shopkeepers were, on average, more competitive than the Somali and Bangladeshi shops in Coke (and Double $\mathrm{O}$ in the case of the latter cohort), a product secured through long established wholesale distribution chains within Delft. Similarly in the case of bread, a product also distributed to all through long established channels, the price difference is negligible 
and partially reflects difference in the quality of bread. The Somali shopkeepers hold an advantage over both South African and Bangladeshi shopkeepers in products that are obtained from wholesalers (such as sugar) where their economy of scale in procurement determines the price at which the goods are retailed.

Figure 5: Absolute difference in price (in cents) between foreign and South African Spazas on key products

\begin{tabular}{|c|c|c|c|c|c|}
\hline$\underset{\mathscr{E}}{\mathscr{E}}$ & 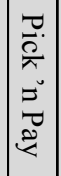 & 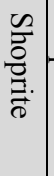 & 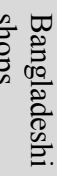 & 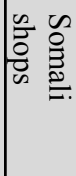 & \\
\hline$\stackrel{\infty}{\omega}$ & \pm & \pm & N & $\frac{\dot{n}}{N}$ & milk \\
\hline \multirow[t]{2}{*}{$\stackrel{ \pm}{=}$} & $\begin{array}{l} \pm \\
v \\
v\end{array}$ & $\stackrel{ \pm}{ \pm}$ & $\stackrel{\dot{N}}{\perp}$ & $\dot{\omega}$ & eggs \\
\hline & & & $\dot{1}$ & $\frac{1}{n}$ & $1 / 2$ loaf \\
\hline \multirow[t]{2}{*}{$\begin{array}{l}\dot{1} \\
\dot{2}\end{array}$} & $\frac{1}{8}$ & $\dot{\hat{N}}$ & $\dot{\sim}$ & $\frac{1}{5}$ & loaf \\
\hline & & & $\dot{b}$ & $a$ & $250 \mathrm{~g}$ sugar \\
\hline$\underset{\sim}{+}$ & \pm & \pm & $\dot{\sim}$ & $\stackrel{1}{\sqsupset}$ & $500 \mathrm{~g}$ sugar \\
\hline \pm & $\begin{array}{l}\dot{n} \\
\dot{\infty}\end{array}$ & $\dot{\dot{u}}$ & & $\dot{\infty}$ & $340 \mathrm{ml}$ coke \\
\hline$\stackrel{ \pm}{\omega}$ & & $\frac{ \pm}{\hat{N}}$ & $\stackrel{+}{\omega}$ & $\stackrel{ \pm}{\omega}$ & $450 \mathrm{ml}$ coke \\
\hline \multirow[t]{4}{*}{$\stackrel{+}{\omega}$} & $\begin{array}{l}+ \\
\text { un } \\
u\end{array}$ & & $\stackrel{+}{\infty}$ & $0 \pm$ & $1.5 \mathrm{~L}$ coke \\
\hline & 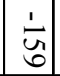 & 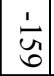 & d & N & Jive \\
\hline & & & 6 & 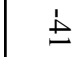 & Double O \\
\hline & & & w & $\infty$ & $\begin{array}{l}\text { Premium } \\
\text { Cigarettes }\end{array}$ \\
\hline
\end{tabular}


Figure 6: Comparative Aggregate Prices (ZAR)

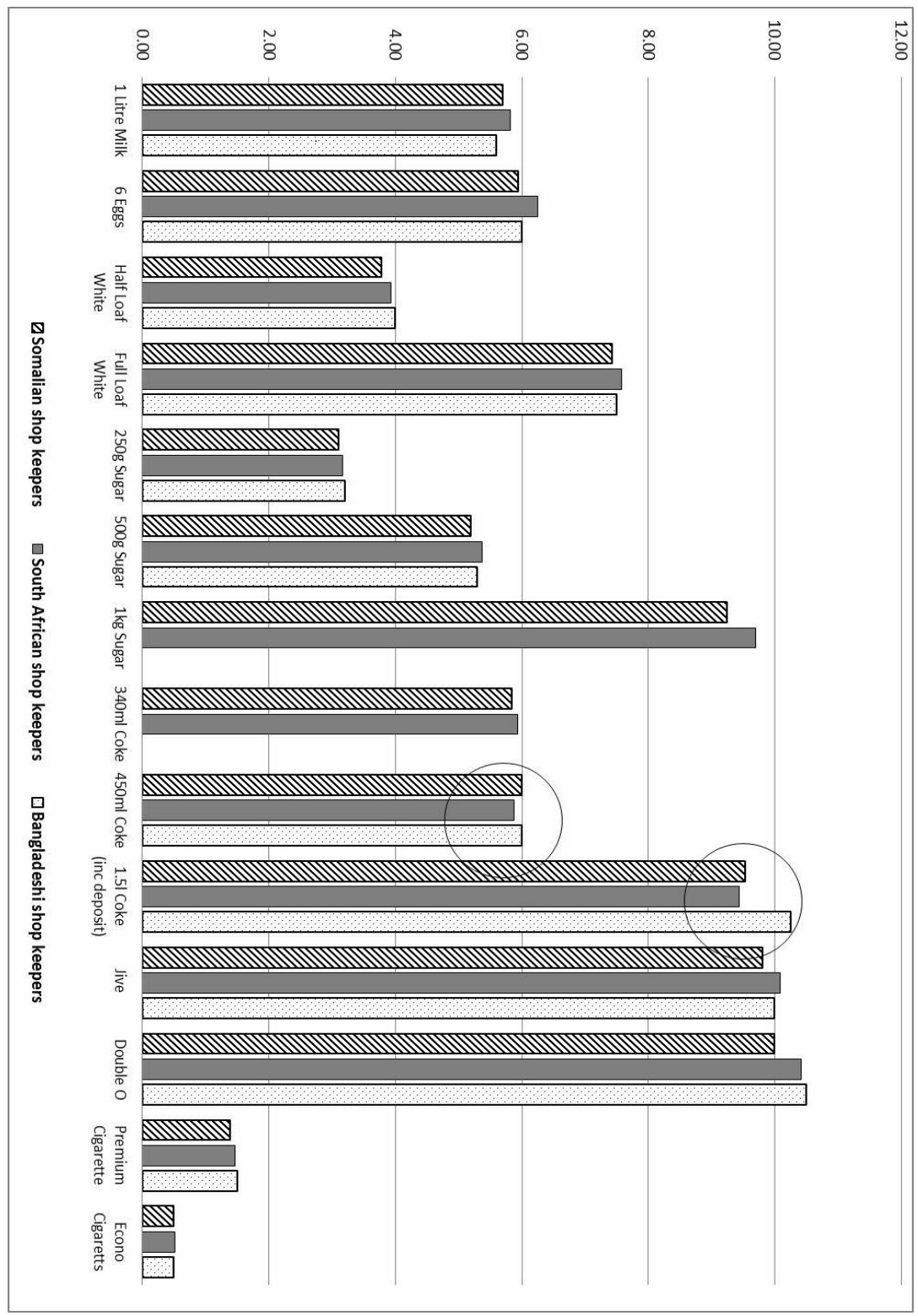


Figure 7: Price Variation (in ZAR), Standard Deviation of Mean

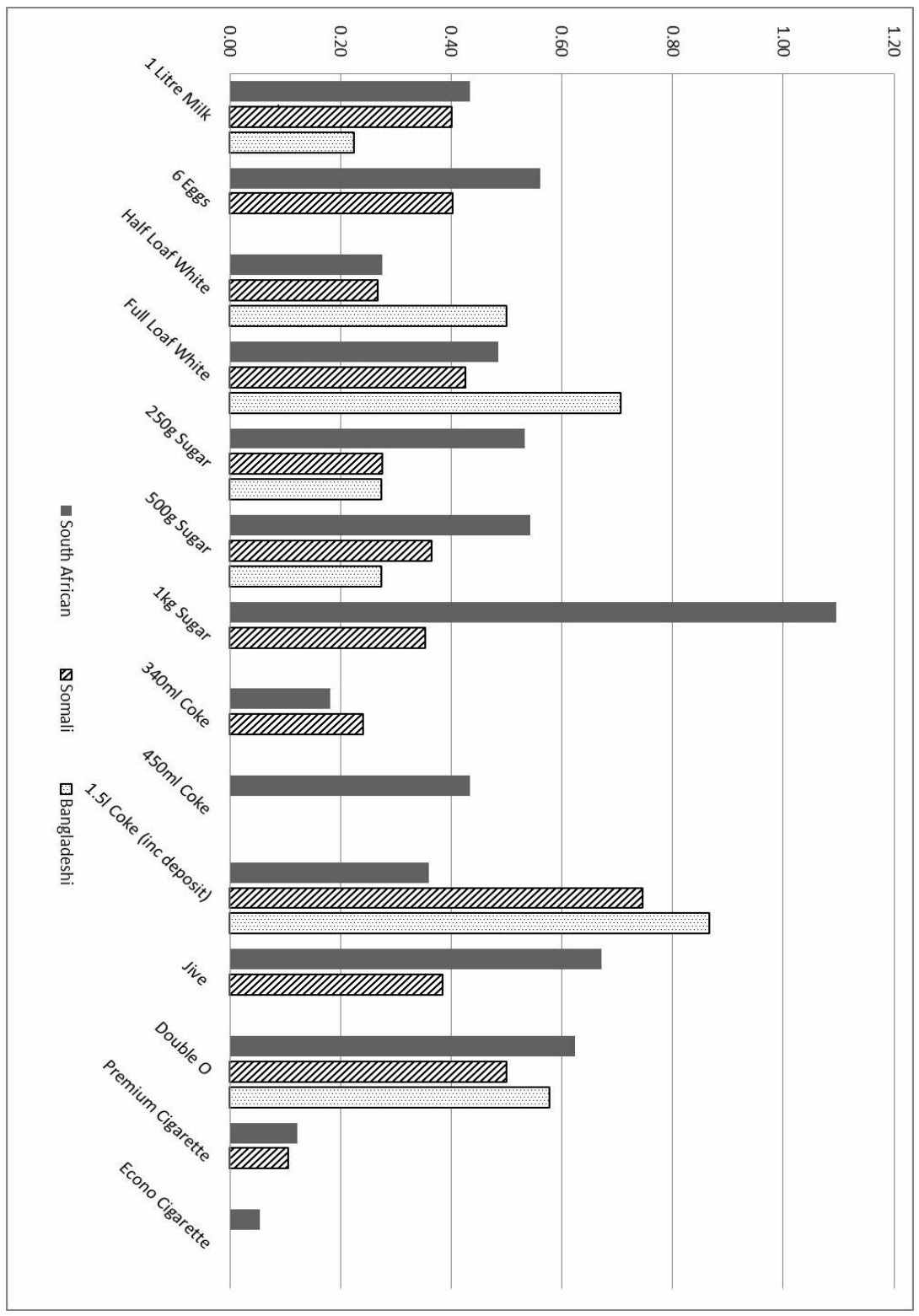


The research found price variation among all three cohorts with the greatest price variation amongst the South African shops. This is understandable, given that the South African shopkeeper cohort includes very small, survivalist businesses that simply cannot discount, and microenterprises that seek to match the price in competing foreigner stores on basic necessities to maintain their customer base. The scale of price variation within each cohort, in terms of the standard deviation of the mean, is shown in Figure 7.

The price differential between the average South African spaza shop and the average prices in foreigner run stores is sufficiently large to put marginally profitable stores out of business. At the spaza shop focus group discussion, for example, we heard the story of one shopkeeper who had been in business for 14 years and whose bread sales declined from over 100 loaves per day to less than seven. Similarly, a respondent in the field interviews stated:

I noticed this change [the arrival of foreigner competition], because I was selling 150 loaves of bread per day, but now I only sell 30 .

Another shopkeeper spoke about how competition had dramatically impacted on her business to the point where her husband, whose business was supplying spaza shops with crisps, accused her of concealing the profits from him. But whilst marginal stores have clearly lost business, most South African micro-entrepreneurs have sought to retain their customers through lowering their prices. Whilst the comparison of aggregate prices implies that South African micro-entrepreneurs are unable to compete with the Somali and Bangladeshi stores, it obscures the fact that some local storekeepers have responded through lowering the prices on certain items. The percentage of local spazas whose prices on the surveyed items was more competitive than the average price in Somali stores in shown in Figure 8. In this regard it is important to recognise that though the prices in the South African shops are generally higher than those in the Somali and Bangladeshi store, the prices of basic necessities are competitive in relation to high street retail stores such as Shoprite, Pick 'n Pay, and Spar (Figure 5). 
Figure 8: Items sold in South African spaza (\% of stores) cheaper than the average price in Somali spazas

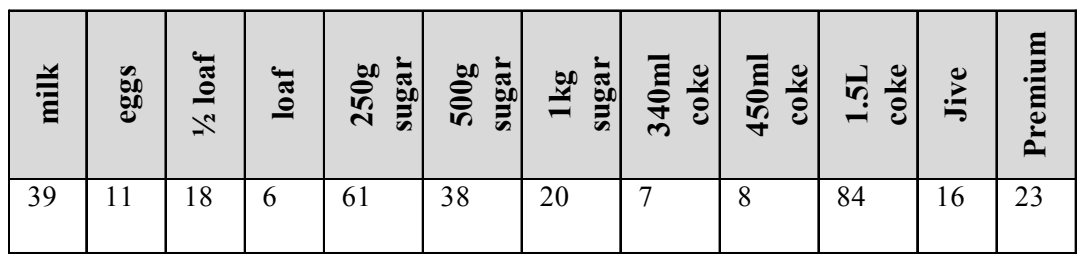

\section{Large businesses versus small}

Several business practices contribute to the price competitive advantages of foreign shops including having a strong role in the supply-chain, access to financial resources, and daily operating practices. An important business advantage of Somali shopkeepers, for example, lies in the semi co-operative supply system through which the shop owners procure their goods from wholesalers and manufacturers. This was confirmed by the shop-owners themselves, but also by a Somali informant who personally negotiated a bulk discount supply agreement with a wholesaler. Each business thus benefits from a procurement and distribution chain that supports multiple stores. As a result of their scale of operation, each buying collective, of which there are several in Delft based on ownership and social ties, is able to secure premium terms from suppliers and can reduce transport costs and ensure that shops within the group receive an uninterrupted supply of merchandise.

In financial terms, the majority of foreign spazas equate to small size enterprises rather than micro-enterprises, as the scale of their operation and turnover is significantly greater than that of the average South African spaza. Somali informants said that it costs new entrants between R30,000R40,000 $(\$ 4,477-\$ 5,970)$ to enter the market, whereas the average South African starts their business will less than R5,000 (\$746). Most Somali shops are co-owned by several investors who look to grow their capital collectively, and then reinvest in further stores, rather than by single investors. Often these investors are drawn from kin groups but not always. Thus a key element in the success of Somali stores is the collective investment in stock and the sharing of financial risk amongst several partners.

Through informal discussions and proxy indicators, we learnt that well positioned foreign-run stores are capable of earning between R15,000 (US\$2,150) and R20,000 (US\$2,850) profit per month. The average South African shopkeeper earns considerably less than this amount, as evident by 
the decision so many have taken to giving up their business and receive a monthly rental of approximately R1,500 from an immigrant shopkeeper who then operates from their premises. South African operators, who commonly do not possess their own vehicle, have to utilise public transport to access the wholesalers. An initiative to achieve a South African purchasing cooperative (the Delft Tuck Shop Association) to overcome this hurdle was unsuccessful and floundered, principally because South Africans have historically relied on extended family networks where reciprocity and trust is secure. According to one South African spaza shop owner,

...coloured and black people (spaza owners) think about themselves only. They think about how they themselves work hard, and the partner does not. They don't always trust each other. And Somalians do not seem to have this problem.

In terms of operating practice, the foreigner run spaza shopkeepers commonly reside within the shop where they have access to a toilet and utilities. Here they 'eat, sleep and cook'. Many residents cited this practice as one reason why they see Somali spazas as unhygienic. The research found that the vast majority of the foreigner shops are run by employees who are remunerated about $\mathrm{R} 1,000(\$ 149)$ per month which, given the long hours they work, is below the minimum wage (R6.90 per hour or approximately $\mathrm{R} 1,300 / \$ 193$ per month). It is common for two or more individuals to run a single shop, working in shifts. The majority are young men, some in their late teens. Some of these may be co-owners of the shop, but others work for relatively wealthy entrepreneurs, some who once ran spazas and have now grown their business interests to comprise a number of units. Although precise information on these business arrangements is difficult to obtain, a few of these entrepreneurs reportedly operate up to a dozen shops.

Product diversity and range is also an important aspect to competitive advantage of foreign run businesses. As township residents acquired more disposable income in the late 1990s - partially as a result of the generalised economic growth since the turn of the new millennium and partially through the impact of welfare transfers - their expectations changed. Customers now had the disposable income to purchase a more diversified range of products. A detailed investigation of the spaza market in the Cape metro-region, undertaken in 2002-03, found that spaza customers were willing to spend more money at spazas, but demanded a greater range of product choices, more competitive prices, and better service (Bear et al 2005). 
Local spaza entrepreneurs failed to interpret this market, whereas foreigners did. Although they recognized the need for greater product diversity, locals assumed that their place in the market was relatively secure. This false sense of security was premised on a lack of competition as all provided a similar retail service. The Bear et al study predicted that the spaza market would shrink as customers shifted their expending towards supermarkets and wholesalers, and indeed concluded that the spaza market was not working. However, an alternative explanation is now available - foreign run stores have taken the place of wholesalers by reducing prices and diversifying their product range. In this sense then the spaza market no longer exists as it did ten years ago for either the shopkeeper or the consumer.

\section{South African responses}

The market dominance of the foreign spaza entrepreneur in Delft has taken around five years despite the significant setbacks experienced by earlier generations of store in the 2008 xenophobic attacks. Nevertheless, there remain some successful South African spaza micro-entrepreneurs whose scale of operation and business sophistication enables them effectively to compete. These businessmen and women characteristically run several different kinds of enterprise and/or have a formal sector income, spreading their business investments between the spaza, a taxi business, and a shebeen (illegal liquor retailing) or tavern. The majority of South African shopkeepers, however, have either gone out of business or seen their profitability substantially decline.

To explore the extent of this impact of these changes within the spaza market we asked informants from the household survey to report on whether they had run a spaza or house shop in the last five years. Among those who answered affirmatively, the respondents were then questioned on the duration of that business and, if no longer running, about the cause of its demise. The research found that $11(22 \%)$ households had run spazas within this timeframe. In all but one case, these businesses had operated for between three months and three years, though one individual had been selling sweets and chips from the day she settled in Delft (about 15 years ago). None of these businesses continued to trade. Their main customers, when operational, were adults buying bread and milk and other basic necessities, and children buying chips, sweets, and soft drinks.

The reasons for their decline varied. Four of the informants (36\%) closed their business because of competition from foreign spazas, blaming the 
Somali shopkeepers who were the first to arrive in Delft. The main reason reported for their business decline was their inability to match the Somali prices and the changing business relationships with wholesale distributors who were no longer willing to supply small shops. Thus, before the rise of foreign spazas, house shops were able to benefit from wholesale distribution networks. Informants report that some distributors (such as the 'chip van') have become unwilling to supply house shops. According to some respondents, the buying power of the new spaza entrepreneurs has become sufficiently large as to exert pressure on suppliers to behave anticompetitively.

Notably, competition from foreigner shopkeepers was not the only reason for business closure, and in seven of the cases other factors were cited. In two cases, the businesses were transferred to other family members who continue to trade. Several of the businesses went bankrupt because of debt as a result of extending credit to their customers. One informant lost his business as a consequence of drug addiction. Another claimed that the business was destroyed through witchcraft as a result of the evil intentions of jealous persons. One spoke about the setback of crime having had her stock stolen and being unable to recover from the economic shock. One ran a shebeen that was forcibly shut down after police raids.

The survey sought to gauge the opinion of residents on the viability of running spaza businesses in Delft. Their views were divided: 19 informants (38\%) had a positive outlook, seeing scope for new businesses, whereas just under two thirds of the informants (31) (63\%) felt that the market was overtraded. The differences of opinion are correlated to the demographic profile of the informant: $86 \%$ of coloured informants expressed a positive outlook towards business opportunities in the spaza market, whereas only $20 \%$ of black informants felt the same sentiment. Many informants spoke about the unassailable competitive advantage of foreign spaza entrepreneurs, given the difficulty to achieve cooperative buying in order to be price competitive. In response to the question, one informant said that there was no further scope for local spazas because 'the Somalis have taken most of the opportunities and offer cheap prices'. Another said:

Locals will find it tough to compete against Somali prices. The fact that they offer credit, cheaper products, as well as alternative products [i.e. generic brands] if one cannot buy expensive ones. Operating times are more convenient as these shops open between 5 and $6 \mathrm{am}$ and close after $10 \mathrm{pm}$. [They are] always willing to assist customers and get the sale. 
Implicit in this statement is recognition of the benefits of customer friendly practices. Thus while some of the respondents were critical of the aggressive price competition of these shopkeepers, others saw opportunities arising from the limitations in foreign practices with several saying that local spaza owners could exploit a business advantage through being more hygienic, polite or culturally connected to their customer base than the foreigners. As a Xhosa, said one informant, 'I would do businesses with another Xhosa if they could offer the prices of the Somalis'.

A number of South African operated spazas have sought to deal with the increased competition from the foreigner operators through shifting the focus of their business away from groceries. The most notable strategy in this respect is the sale of liquor. This strategy gives many local microentrepreneurs an advantage over Somali, Bangladeshi and Muslim South Africans who, for religious reasons, will not sell liquor. Additionally, there is significant fear of the legal consequences of engaging in illicit liquor sales, given the current heightening of law enforcement against shebeens in Cape Town. Notably, of all the South African run spazas identified in Delft, one in five stores sells liquor (19\%). Another common strategy is to turn their spazas into gaming shops, providing patrons with arcade games and pool tables. Again this strategy sets the South African spaza apart from foreign businesses as gaming shops present a relatively high security risk because customers must enter into the building. A further coping strategy which sustains the more competitive local spazas is the provision of take-away meals. The foreign run spazas, in contrast, do not provide takeaways, not least because the market has significant competition from house shops, especially over the weekends. In addition, a number of the informants in the household survey regard foreign run spazas as unhygienic venues and expressed the opinion that they would not purchase fresh product or prepared food from these stores.

Among the least competitive spaza shops, the main coping strategy has been a quiet surrender of their business to foreign entrepreneurs with some simply closing shop and others selling or renting to foreign investors. We estimate that this process has seen transfer of about 70 spaza shops from South Africans to foreigners in the last five years - some $40 \%$ of the total market. Where these South Africans own the spaza premises, they commonly settle for the monthly income from rent that averages around R1,500 (\$225) per month. We found just one local spaza that has entered into profit share partnerships, and another where a Somali shopkeeper offered to pay the 
South African R500 (\$75) per month to keep his store closed. The final strategy has been organised resistance. A group of South African spaza micro-entrepreneurs have formed an organisational entity, known as the concerned tuck-shop owners, to campaign for the 'enforcement' of a 100metre exclusion zone around every established spaza shop. To date their efforts have proved futile.

\section{Conclusions}

The last five years has witnessed a significant transformation in the scope and nature of the informal economy in the Delft township of Cape Town, at least as in regard of the most common enterprise, the spaza shop. Not only has the number of spaza shops grown over this time, but the composition of their ownership has also changed dramatically due to an influx of foreign business people, especially from Somalia. Furthermore, and most importantly, the dominant spaza business model has changed dramatically as immigrants have introduced a more entrepreneurial business model based on price competitiveness through co-operative ownership, procurement and distribution practices, supplanting the survivalist practices of South Africans.

As systematically demonstrated through this research, geographic locality is important in determining market advantage, though even with the advantage of locality the cheapest shop will dominate under competitive economic conditions. The last five years has witnessed a price war that has ruptured the once predominant business model in the local spaza market when prices were evenly matched and positioned, through informal consensus, at a price point where even the weakest competitor could remain in business. In short, the low-profit but low entry-cost 'survivalist' model of South African shopkeepers has lost out to a high-profit, high entry-cost entrepreneurial model of foreign investors. The conflict between South African and foreign shopkeepers is thus less about nationality than it is about contradictory business practices.

South Africans have reacted in diverse ways to this transformation. The consumer has, by and large, welcomed the foreign spaza entrepreneurs, benefiting from the reduced prices and improved service. Some local spaza micro-entrepreneurs may, ultimately, also benefit from these changes in the market through their efforts to improve their competitiveness in response. South African shopkeepers have had to adapt dramatically. Most now rent out their shop space to foreigners, while others have diversified their business through selling alcohol and installing arcade games. Whether 
these strategies will enable them to retain a foothold in the spaza market is unknown, but it is almost certain that new entrants from the marginalised and poor will struggle to make it in this fiercely competitive market. In effect then, the spaza market is no longer the preserve of the economically marginalised, but is closer in practice and, for some, in profits to the formal sector. In a paradoxical way then, the rise of the Somali shopkeeper heralds the death of the traditional spaza shop, and the rise of the wholesaler and supermarket.

\section{Note}

1. The authors acknowledge funding from the African Centre for Citizenship and Democracy at the School of Government (ACCEDE), University of Western Cape and research support from the Sustainable Livelihoods Foundation (SLF).

\section{References}

Bear, M, P Bradnum, S Tladi and D Pedro (2005) Making Retail Markets Work for the Poor - why and how triple trust organisation decided to intervene in the Spaza market in South Africa. Washington, D.C.: The SEEP Network.

Becker, KF (2004) 'The informal economy'. Stockholm: ORGUT Consulting AB for the Department for Infrastructure and Economic Co-operation (SIDA).

Cant, M and L van Scheers (2007) 'Analysing the influence of the spaza shop on the cash and carry wholesaler in the South African distribution channel'. Tokyo: Proceedings of the International Business Academics Consortium Conference, Tokyo.

CensusPlus 2007. Community Survey 2007 Database. www.statssa.gov.za. Accessed 12 March 2009.

Charman, A and L Petersen (2007) Informal Economy Study: trade component. Micro economic development strategy. Cape Town: Provincial Government of Western Cape.

Charman, A and L Petersen (2010) 'An investigation of characteristics distinguishing "entrepreneurs" from the "self-employed" in South African's informal economy". Johannesburg: Unpublished Paper presented at the WITS Conference on Entrepreneurship.

Charman, A and L Piper (2011) 'Conflict and cohesion in the informal economy: a reassessment of the mobilisation of xenophobic violence in the case of spaza shops in Delft South, Cape Town, South Africa'. Cape Town: Unpublished paper presentation to Department of Political Studies, University of the Western Cape. 
Chebelyon-Dalizu, L, Z Garbowitz, A Hause and D Thomas (2011) 'Strengthening spaza shops in Monwabisi Park, Cape Town’. Unpublished report. Worcester, MA: Worcester Polytechnic Institute.

Devey R, C Skinner and I Valodia (2006) 'Second best? Trends and linkages in the informal economy in South Africa'. University of KwaZulu-Natal Development Policy Research Unit Working Paper 06(102). Durban: UKZN.

Knowledge Link Services (2009) 'An audit of spaza shops in Khayelitsha, Cape Town in 2009'. Cape Town: City of Cape Town. Unpublished report.

Ligthelm, AA (2005) 'Informal retailing through home-based micro-enterprises: the role of spaza shops'. Development Southern Africa. 22(2), 199-214.

Ligthelm, AA (2008) 'A targeted approach to informal business development: the entrepreneurial route', Development Southern Africa 25(4).

Maloney, W (2004) 'Informality revisited', World Development 32(7).

Marketing Mix (1995) 'Pick 'n Pay's tills ring the changes', Johannesburg: February Edition.

Meagher, K (1995) 'Crisis, informalization and the urban informal sector in subSaharan Africa', Development and Change 26.

Perry, M (1989) Informal Retail Business. Johannesburg: Perry and Associates.

Petersen, L and A Charman (2008) 'Making markets work for the poor: understanding the informal economy of Limpopo Province'. Research consultancy for the Limpopo Local Economic Development Programme. Polokwane.

Seekings, J, T Jooste, S Muyeba, M Coqui and M Russel (2010) 'The social consequences of established "mixed" neighbourhoods: does the mechanism for selecting beneficiaries for low-income housing projects affect the quality of the ensuing “community": and the likelihood of violence conflict?' Research Report. Centre for Social Science Research. Cape Town. University of Cape Town.

SPAZA News (2010) 'Are foreigners killing your Spaza shop?' Issue 6, August 2010. http://www.spazanews.co.za/. Accessed 15 February 2012.

Statistics South Africa (2010) Quarterly Labour Force Survey -Quarter 1. Pretoria, South Africa.

Valodia, I, R Davies, M Altman and J Thurlow (2007) 'Economic behaviour in South Africa's informal economy'. Report to the Conflict and Governance Facility (CAGE). Pretoria: Human Sciences Research Council.

Van der Berg, S and M Louw (2003) 'Changing patterns of South African income distribution: Towards time series estimates of distribution and poverty'. Paper to the Conference of the Economic Society of South Africa, Stellenbosch, 1719 September. 